\title{
Effectiveness of Kangkungan (Ipomea Crassicaulis) to Reduce BOD Levels of Tofu Waste Using the Phytoremediator Method
}

\author{
D. Widyastuti*, D. Suprayitno** \\ *Institut Pertanian Malang \\ ** Institut Pertanian Malang \\ DOI: 10.29322/IJSRP.10.10.2020.p10611 \\ http://dx.doi.org/10.29322/IJSRP.10.10.2020.p10611
}

\begin{abstract}
Tofu is one of the foodstuffs favored by the people of Indonesia, this is why there are many tofu industries in Indonesia. The tofu industry is a fast growing industry in Indonesia. There are about 75 tofu industries in Malang city, where most of the tofu industry is in the form of home industry. Wastewater from the tofu industry is produced from the washing, boiling, pressing and molding processes of tofu, so the quantity of waste water produced is quite high. Tofu liquid waste contains very high pollutants or organic pollutants which can cause environmental pollution because it contains organic substances that cause rapid microbial growth in the waters. Considering the high potential for water pollution due to the tofu-making industrial liquid waste, a strategy is needed to control water pollution by treating the tofu industrial liquid waste before discharging it to the environment. One way is by means of phytoremediation. Phytoremediation is a method of removing pollutants using plants. Aquatic plants that are often used include water hyacinth, Kangkungan (Ipomoea crassicaulis), umbrella papyrus, and water bamboo. Phytoremediation techniques are widely applied in several countries, such as Asia, America, and Europe. Kangkungan (Ipomoea crassicaulis) is a type of plant that is easy to breed. This is one of the considerations for using kangkungan (Ipomoea crassicaulis) in phytoremediation. In addition, many types of waste can be processed by kangkungan (Ipomoea crassicaulis). The purpose of this study was to determine the effectiveness of using kangkungan (Ipomoea crassicaulis) in reducing levels of tofu waste. The results of the study showed that tofu liquid waste treatment using the phytoremediation method using kangkungan (Ipomea cracicaulis) was proven to reduce BOD levels in tofu liquid waste.
\end{abstract}

Index Terms- Tofu Waste, Kangkungan, Phytoremediation.

\section{INTRODUCTION}

Tofu is one of the foodstuffs favored by the people of Indonesia, this is why there are many tofu industries in Indonesia. The tofu industry is a fast growing industry in Indonesia. There are about 75 tofu industries in Malang city, where most of the tofu industry is a home industry. Every tofu industry produces tofu every day using $90 \mathrm{~kg}$ of soybeans per day. Meanwhile, for every $1 \mathrm{~kg}$ of soybeans requires 45 liters of water and will produce 43.5 liters of liquid waste. So it can be calculated that the amount of liquid waste discharged into the environment is 3915 liters per day. This of course will pollute the aquatic environment, because almost all tofu industries do not process their liquid waste before it is discharged into the water. Wastewater from the tofu industry is produced from the washing, boiling, pressing and molding processes of tofu, so the quantity of waste water produced is quite high. Tofu liquid waste contains very high organic pollutants or pollutants which can cause environmental pollution because it contains organic substances that cause rapid microbial growth in waters (Ratnani, 2011). This can result in decreased oxygen levels in the waters. In addition, tofu liquid waste also contains suspended substances, resulting in turbidity in the waters. In order to reduce the pollution load, an effective and inexpensive method of processing is required. Tofu industrial liquid waste has COD (Chemical Oxygen Demand) of $5759 \mathrm{mg} / \mathrm{L}$, BOD (Biochemical Oxygen Demand) of $580 \mathrm{mg} / \mathrm{L}$, TSS (Total Suspended Solid) of $552 \mathrm{mg} / \mathrm{L}$, and pH of 3.9. This value is above the quality standard of PerMen LH No. 05/2014 concerning the tofu industrial waste water quality standard, namely BOD (150 mg / L), COD (300 mg / L), TSS (200 mg / L) and pH (6-9). Tofu industrial liquid waste which is disposed of without further processing will cause several problems for the environment. Usually the problem that arises is in the form of deposition and decomposition of organic material in the water bodies receiving the waste which ultimately worsens water quality.

In general, water pollution by tofu industrial wastewater will decrease the dissolved oxygen content in water (due to the breakdown of organic matter) and eventually create an anaerobic atmosphere that will disrupt ecosystems and life in the waters. Considering the high potential for water pollution due to the tofu-making industrial liquid waste, a strategy is needed to control water pollution by treating the tofu industrial liquid waste before discharging it to the environment. One way is by means of phytoremediation. Phytoremediation is a method of removing pollutants using plants. Aquatic plants that are often used include water hyacinth, kangkungan (Ipomoea crassicaulis), umbrella papyrus, and water bamboo. Phytoremediation techniques are widely applied in several countries, such as Asia, America and Europe in dealing with environmental pollution, especially water pollution. One type of plant that is capable of remediating 
waste is kangkungan (Ipomoea crassicaulis). Kangkungan (Ipomoea crassicaulis) is a type of plant that is easy to breed. It is easy to breed, this is one of the considerations for using Kangkungan (Ipomoea crassicaulis) in phytoremediation. In addition, many types of waste can be processed by kangkungan (Ipomoea crassicaulis). The purpose of this study was to determine the effectiveness of using kangkungan (Ipomoea crassicaulis) in reducing levels of tofu waste.

\section{LITERATUR REVIEW}

\section{Tofu Industrial Waste}

Tofu industrial waste is generated from the tofu making process. The waste produced consists of two types, namely solid and liquid. The impact of solid waste has not yet been felt on the environment, because solid waste can be reprocessed into oncom or it can also be made for animal feed such as chickens, ducks, cattle, goats and pigs (Disyamto et al, 2014). Tofu industrial liquid waste is the largest part and has the potential to pollute the environment. Most of the liquid waste produced comes from the thick liquid that is separated from the clumps of tofu in a clumping and filtering process called whey. Other liquid wastes originate in the sorting and cleaning process, stripping the skin, washing and filtering, washing process equipment and floors. The amount of liquid waste produced by the tofu making industry is proportional to the use of water in its processing. The amount of water needed and the amount of liquid waste generated based on the results of existing research is 45 and 43.5 liters for each kilogram of soybean. Biological Oxygen Demand (BOD) is a parameter for assessing the amount of dissolved organic matter and showing the amount of oxygen required by the activity of microorganisms to biodegrade organic substances in liquid waste. Tofu industrial liquid waste contains high dissolved organic materials (Wardana, 2004). A high BOD value indicates that there are many organic compounds in the waste, so that a lot of oxygen is needed by microorganisms to break down organic compounds. A low BOD value indicates the decomposition of organic waste by microorganisms (Zulkifli and Ami, 2001). The impact caused by the pollution of tofu industrial waste organic matter is a disturbance to biotic life, a decrease in water quality caused by an increase in organic matter content (Herlambang, 2002). The resulting liquid waste containing suspended or dissolved solids will undergo physical, chemical and biological changes that will cause health problems because it will produce toxic substances or create a medium for the growth of germs or other harmful germs. If left untreated, the wastewater will turn blackish brown and smell bad. If this waste is channeled into the river it will pollute the river and if it is still used it will cause health problems in the form of itching, diarrhea, cholera, colitis and other diseases, especially those related to dirty water and poor environmental sanitation (Kaswinarni, 2007).

\section{Phytoremediation}

Phytoremediation is the washing out of pollutants that are remediated by plants, including trees, grasses and aquatic plants. This washing can mean the destruction, inactivation or immobilization of pollutants into harmless forms. Phytoremediation is a system that uses plants, where the plants work together with microorganisms in the media to convert, stabilize or destroy contaminants to be less or not dangerous at all, even into materials that are economically useful. Environmental factors that affect the phytoremediation process include types of plants, weather/climate factors, temperature and $\mathrm{pH}$. The mechanism of phytoremediation consists of several basic concepts, namely phytoextraction, phytovolatization, phytodegradation, phytostabilization, rhizofiltration and interactions with pollutant degrading microorganisms (Hidayati, 2005). Biofilter as a way of processing waste by using plants that have rhizosphere microbes have the ability to decompose organic and inorganic objects in wastewater (Suriawiria, 2003). This shows that the ability of aquatic plants to filter dissolved materials in wastewater has the potential to be used as part of the wastewater treatment business. Reed et al. (2005) suggested that in the process of treating wastewater in ponds that uses water plants, there is a process of filtering and absorption by the roots and stems of aquatic plants, the process of exchange and absorption of ions. In addition, water plants also play a role in stabilizing the effects of climate, wind, sunlight and temperature. Phytoremediation is an effort to use plants to reduce waste concentrations and environmental pollution problems either exsitually using artificial ponds or reactors or in-situ (directly in the field) on soil or water contaminated with waste (Soetrisnanto et al. 2012). The liquid waste to be treated is planted with certain plants that are able to absorb, collect and degrade certain pollutants contained in the waste. Aquatic plants can filter, adsorb organic particles and absorb metal ions in wastewater through their roots (Safitri 2009).

\section{Kangkungan (Ipomoea crassicaulis)}

Ipomoea crassicaulis Rob. or better known in the Java region as kangkungan, is a shrub that can reach 2 meters in height, sometimes it can grow taller if there are lots of nutrients in the soil. This plant can be used as an ornamental plant, often grows wild. Grows in humid areas, especially areas that have high moisture content. On the banks of rivers, roadsides and in rice fields. Its fast growth sometimes makes people think that this plant is a weed, so it must be destroyed. Kangkungan usually grows along river banks, moist soil or roadside. Sometimes this plant is also commonly used as an ornamental plant (van Stenis, 1992). According to research conducted by Nailufari (2008), it shows that kangkungan plants can reduce the levels of pollutants in textile dyeing waste such as pH, BOD, COD, TSS, total ammonia and sulfide. This kangkungan plant also has the advantage that it is easy to grow, wild so it is easy to get and this plant can also survive in polluted conditions.

\section{RESEARCH AND METHODOLOGY}

Before doing the experiment, what must be done first is to test the toxicity of the tofu liquid waste and then carry out the acclimatization process which aims to adapt the plants to the climate or temperature in the environment they have just entered. Kangkungan (Ipomoea 
crassicaulis) plants that will be used are acclimatized for one month. The next stage is to prepare the reactor used in this study. There are 4 reactors used in this study, 3 reactor units containing plants while 1 reactor is used as a control. Where each reactor will be given kangkungan (Ipomoea crassicaulis) of $25 \mathrm{gr}, 50 \mathrm{gr}$ and $75 \mathrm{gr}$. The acclimatization process of Kangkungan (Ipomoea crassicaulis) is carried out by planting Kangkungan (Ipomoea crassicaulis) in tofu liquid waste that has been diluted with clean water with a concentration of $25 \%$ (one liter of tofu wastewater is diluted with three liters of clean water/water faucet). The purpose of this acclimatization is to make plants accustomed to the conditions of the waste that will be used in the process of conducting research. Acclimatization is carried out for one month. The implementation stage is the stage of the wastewater treatment process using kangkungan (Ipomoea crassicaulis). Where before this stage is carried out, the BOD content of tofu liquid waste is measured first. After that, the Kangkungan (Ipomoea crassicaulis) plant is continuously fed with tofu waste. Measurement of BOD levels every 2 weeks. The data analysis used was a completely randomized design, with 3 replications each.

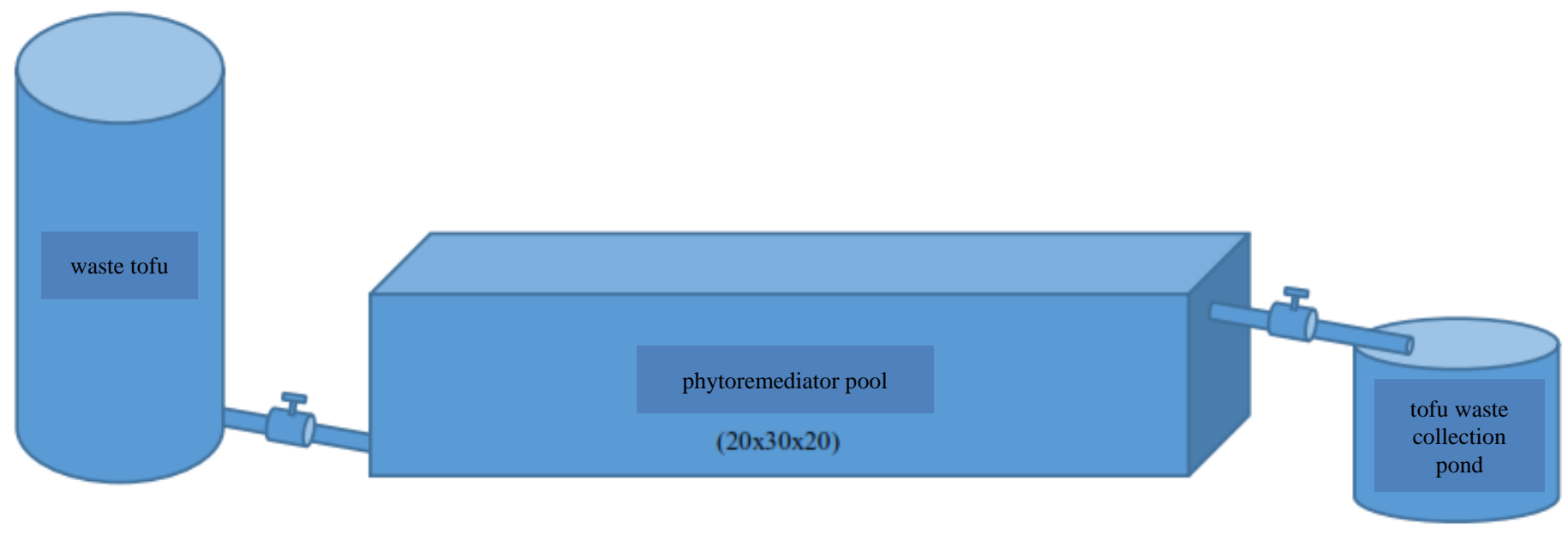

Figure 1. Research Reactor

\section{RESULT AND DISCUSSION}

The characteristics of the tofu waste used in this study were a BOD of $1369 \mathrm{mg} / 1$. before observing the tofu waste, dilution it first for the acclimatization process. After diluting the characteristics of the waste which was diluted into BOD of $921.30 \mathrm{mg} / \mathrm{l}$. In accordance with the Minister of Environment and Forestry Regulation No. 05/2014 concerning the quality standard of waste water for soybean processing businesses and / or activities, which states that the quality standard for BOD content is $150 \mathrm{mg} / 1$. So with the results of the initial analysis it is known that the tofu waste water content does not meet the quality standard requirements if it is directly discharged into water bodies.

The analysis of the waste content is carried out every 2 weeks. The initial BOD content of tofu waste was $921.30 \mathrm{mg} / \mathrm{l}$, far beyond the quality standards set. The amount of BOD content in tofu waste is caused because tofu waste has a high enough protein content, this is in accordance with the statement from Sungkowo, et al. (2015) which states that the large BOD value in tofu industrial waste is due to the high protein which is an organic substance contained in tofu waste so it requires dissolved oxygen for the decomposition process. The value of BOD levels at the end of the observation decreased to $241.77 \mathrm{mg} / 1$ for T1 treatment, $213.89 \mathrm{mg} / 1$ for T2 treatment, and $197.45 \mathrm{mg} / \mathrm{l}$ for T3 treatment. The decrease in BOD levels was also caused by the greater number of kangkungan plants in the sewage treatment reactor when compared to other researchers. The large number of kangkungan plants contained in the sewage treatment reactor causes the plant density to also be high. Treatment using kangkungan (Ipomea cracicaulis) was able to reduce BOD levels in tofu waste. Tofu waste contains a lot of biodegradable materials that can be easily broken down by microorganisms. The use of kangkungan has been proven effective in reducing BOD levels in tofu waste. The process of reducing pollutants in liquid waste using water plants is a collaboration between plants and microbes in these plants (Nurkemalasari et al., 2013). The rate of BOD reduction in tofu waste by using the phytoremediation method using kangkungan plants can be seen in Figure 1 below.

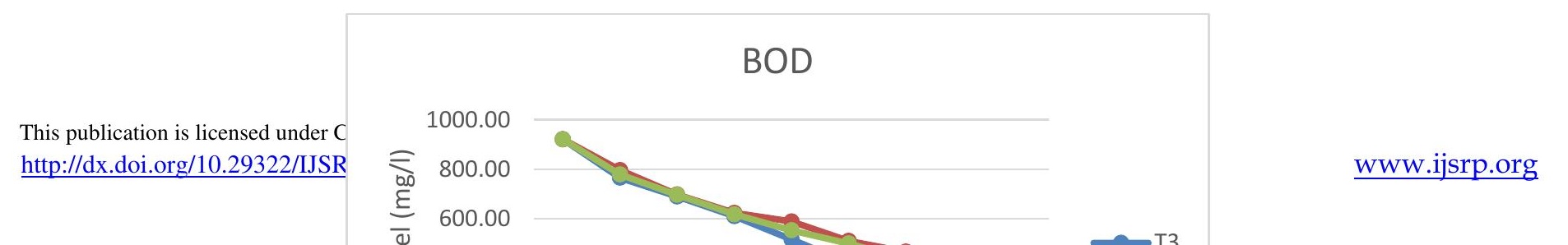


Figure 1. BOD Rate Graph

The results showed that the most effective reduction in BOD levels was in T3 treatment, treatment with 75 gr of kangkungan. This is because the number of plants in the $\mathrm{T} 3$ reactor is the most so that the plant density in the $\mathrm{T} 3$ reactor is tighter than in the other reactors. Where the higher the plant density, the more effective the absorption of BOD by plant roots will be. With the higher the density of the plant, the microorganisms will grow around the roots, resulting in the process of decomposing contaminants by microbial activity around the roots that will take place more (Euis, 2011). BOD is an indicator of organic pollution in waters. Kangkungan (Ipomea cracicaulis) is a plant that is sensitive to conditions where a nutrient found in water is insufficient and has a good response to high nutrient concentrations.

The decrease in BOD levels in this study was caused by the phytoremediation process that occurred in kangkungan plants which began in the rhizofiltration process, the adsorption process or deposition of contaminants in plant roots then absorbed by the roots and entered into the stems and spread to all parts of the plant. This process, organic substances will undergo a biological reaction and accumulate in the plant stems and then continue to the leaves (Sriyana, 2006). The lowering of BOD levels is due to the activity of microorganisms that convert complex organic compounds into simpler compounds. By changing these complex compounds into simpler compounds, these compounds will be more easily absorbed by the roots of kangkungan. By reducing the amount of organic material contained in tofu liquid waste, the population of microorganisms will decrease so that the oxygen needed to decompose these complex compounds is also reduced. With the decrease in oxygen needed, the dissolved oxygen value will be higher so that the BOD value will decrease. Not all plants can be used in the phytoremediation process, this is because not all plants can carry out the metabolic processes, volatilization and accumulation of all pollutants with the same mechanism. Apart from the types of plants, environmental conditions also have an influence on the plant growth process used for the phytoremediation method. If the plants grow well, the accumulation process of contamination using the phytoremediation method can run optimally.

\section{CONCLUSION}

The results of this study concluded that the use of kangkungan (Ipomea cracicaulis) to treat liquid waste tofu by using the phytoremediation method was proven effective in reducing BOD levels in tofu waste. There is a significant difference in the BOD levels of tofu waste before processing with the phytoremediation method with kangkungan plants with the BOD levels of tofu wastewater after processing. In addition, the large number of plants also makes a difference in reducing the BOD levels of tofu liquid waste. The number of kangkungan (Ipomea cracicaulis) plants as much as 75 grams was proven to be effective in reducing the BOD levels of tofu wastewater from $921.30 \mathrm{mg} / 1$ to $197.45 \mathrm{mg} / 1$

\section{ACKNOWLEDGMENT}

Thank you to the tofu industry owners in Sumpil Street, Malang City, East Javw and all those who have helped a lot in completing this research.

\section{REFERENCES}

[1] Arya Wardhana, Wisnu. 2004. Dampak Pencemaran Lingkungan. Penerbit Andi: Yogyakarta.

[2] Disyamto, Dwi Azrul, Shinta Elystia, Ivnaini Andesgur. 2014. Pengolahan Limbah Cair Industri Tahu Menggunakan Tanaman Thypa Latifolia dengan Proses Fitoremediasi. JOMFTEKNIK 1 (2):1-13

[3] Euis Nurul Hidayah, Wahyu Adita. 2010. Potensi dan Pengaruh Tanaman Pada Pengolahan Air Limbah Domestik dengan Sistem Constructed wetland, Jurusan Teknik Lingkungan, Fakultas Teknik, Universitas Pembangunan Nasional "Veteran”. Jawa Timur.

[4] Herlambang, Arie. 2002. Teknologi Pengolahan Limbah Cair Industri. TIEMLBPPT

[5] Hidayati, Nuril. 2005. Fitoremediasi Dan Potensi Tumbuhan Hiperakumulator. Hayati Journal of Biosciences 12 (1). Elsevier: 35-40.

[6] Kaswinarni, F. 2007. Kajian Teknis Pengolahan Limbah Padat dan Cair Industri Tahu. (Tesis). Semarang: Program Study Magister Ilmu Lingkungan Program Pascasarjana Universitas Diponegoro. 
[7] KementerianLingkungan Hidup. (2014). Peraturan Menteri Lingkungan Hidup Republik Indonesia Nomor 5 Tahun 2014 Tentang Baku Mutu Air Limbah. Jakarta: Kementerian Lingkungan Hidup Republik Indonesia.

[8] Nailufary, L., 2008, Pengolahan Air Limbah Pencelupan Tekstil Menggunakan Biofilter Tanaman Kangkungan dalam Sistem Batch (Curah) Teraerasi, Skripsi, Universitas Udayana, Bali

[9] Nurkemalasari, Rika., Sutisna, M., Wardhani, E. 2013. Fitoremediasi Limbah Cair Tapioka Dengan Menggunakan Tumbuhan Kangkung Air (Ipomea aquatica). Jurnal Reka Lingkungan. Institut Teknologi Nasional. 1(2), 81-92

[10] Ratnani, R.,D., Indah., H., Laeli., K., 2011. Pemanfaatan Eceng Gondok (Eichornia Crassipes) Untuk Menurunkan Kandungan COD (Chemical Oxygen Demond), pH, Bau, Dan Warna Pada Limbah Cair Tahu. Majalah Ilmiah Momentum. Fakultas Teknik Universitas Wahid Hasyim. 7(1), 41-47.

[11] Silviana, Safitri. 2009. Perencanaan Sistem Instalasi Pengolahan Air Limbah. UI Press : Jakarta.

[12] Soetrisnanto et al. 2012. Application Of Phytoremediation For Herbal Medicine Waste And Its Utilization For Protein Production. Reaktor Chemical Engineering Journal. 14(2), 129-134

[13] Sriyana, H.Y., 2006, "Kemampuan Eceng Gondok dalam Menurunkan Kadar Pb(II) dan Cr (VI) Pada Limbah dengan Sistem Air Mengalir dan Sistem Air Menggenang“, Tesis S2, Fakultas Teknik, Jurusan Teknik Kimia UGM, Yogyakarta.

[14] Sungkowo, T. H., Elystia, S., \& Andesgur, I. (2015). Pengolahan Limbah Cair Industri Tahu Menggunakan Tanaman Typha Latifolia dan Eceng Gondok dengan Metode Fitoremediasi. Jurnal Online Mahasiswa (JOM) Bidang Teknik dan Sains, 2(2):1-8.

[15] Zulkifli dan Ami, A. 2001. Pengolahan Limbah Cair Pabrik Tahu dengan Rotating Biological Contactor (RBC) pada Skala Laboratorium. Limnotek. Vol, VIII. No, 1. :21-34

\section{AUTHORS}

First Author - Diena Widyastuti, lecture, Malang Agriculture Institute

Second Author - Didik Suprayitno, lecture, Malang Agriculture Institute.

Third Author - Gettik Andri Purwanti, lecture, Malang Agriculture Institute.

Correspondence Author - Diena Widyastuti, dienawidyastuti3008@gmail.com 